\title{
Anxiolytic- and antidepressant-like effects of an aqueous extract of Tanacetum parthenium L. Schultz-Bip (Asteraceae) in mice
}

\author{
Jorge Cárdenas $^{\mathrm{a}}$, Valeria Reyes-Pérez ${ }^{\mathrm{a}, \mathrm{b}, \mathrm{c}}$, María Dolores Hernández-Navarro ${ }^{\mathrm{b}}$, Ana \\ María Dorantes-Barrón ${ }^{c}$, Salvador Almazán ${ }^{\mathrm{d}}$, Rosa Estrada-Reyes ${ }^{\mathrm{c}, *}$ \\ a Instituto de Química, Universidad Nacional Autónoma de México (UNAM), Coyoacán, 04510 Ciudad de México (CDMX), México \\ b Facultad de Química, Universidad Autónoma del Estado de México (UAEM), Toluca, Estado de México, México \\ c Laboratorio de Fitofarmacología, Instituto Nacional de Psiquiatría Ramón de la Fuente Muñiz (INPRFM), Calzada México-Xochimilco 101, Col. San \\ Lorenzo Huipulco, Del. Tlalpan, 14370 CDMX, México \\ d Departamento de Bioelectrónica, Dirección de Investigaciones en Neurociencias, Instituto Nacional de Psiquiatría Ramón de la Fuente Muñiz (INPRFM), \\ Calzada México-Xochimilco 101, Col. San Lorenzo Huipulco, Del. Tlalpan, 14370 CDMX, México
}

\section{A R T I C L E I N F O}

Chemical compounds studied in this article: Alprazolam (PubChem CID: 2118) Muscimol (PubChem CID: 4266) Picrotoxin (PubChem CID: 518601) Fluoxetine (PubChem CID: 62857) p-chlorophenylalanine (PubChem CID: 2733277)

Diazepam (PubChem CID: 3016)

Keywords:

Tanacetum parthenium

Anxiety

Antidepressant

GABAergic system

\begin{abstract}
A B S T R A C T
Aim: Tanacetum parthenium L. Schultz-Bip (Asteraceae) is widely used worldwide in traditional medicine for the treatment of convulsions and culture-bound syndromes such as susto (fear). The aim of this work was to evaluate the anxiolytic- and antidepressant-like effects of an aqueous extract of T. parthenium in behavioral paradigms in mice. The effects of $T$. parthenium were compared with those produced by anxiolytic and antidepressant drugs. We carried out the chemical characterization of the main constituents of T. parthenium. The involvement with the GABAergic and serotoninergic neurotransmitter systems were explored be means of synergic and antagonist experiments.

Materials and methods: The anxiolytic-like effect was evaluated using the Burying Behavior Test (BBT) and the Elevated Plus-Maze Test (PMT). The antidepressant-like effect was evaluated in the Forced Swimming Test (FST), and ambulatory activity was assessed in the Open Field Test (OFT). Employing the behavioral tests, synergism and antagonism experiments with Alprazolam, Muscimol, and Picrotoxin were carried out in the PMT. In a series of independent experiments, concomitant administration of T. parthenium and Alprazolam, Fluoxetine, or $p$-chlorophenylalanine were conducted in the FST.

For chemical characterization, High-Performance Liquid Chromatography-Electro Spray Ionization-Mass Spectrometry (HPLC-ESI-MS) analysis was performed.

Results: T. parthenium exerts clear anxiolytic- and antidepressant-like effects in mice, without affecting the ambulatory activity of the experimental subjects.

Conclusions: Anxiolytic- and antidepressant-like T. parthenium effects result, at least part from the involvement of the GABAergic system. Our results support the use of Tanacetum parthenium in traditional medicine and suggest its therapeutic potential in the comorbid anxiety and depression.
\end{abstract}

\section{Introduction}

Tanacetum parthenium L. Schultz-Bip (Asteraceae) is a bushy aromatic plant with feathery leaves and daisy like flowers, due resemblance to matricaria, it is known as feverfew, is a perennial species native to Eurasia, specifically the Balkan Peninsula, Anatolia and the Caucasus. However, cultivation has spread it around the world, and it is now also found in the remainder of Europe, in North America, and in Chile (Jeffrey, 2001; Pareek et al., 2011). It has adapted to Mexico, where it is known by several popular synonyms, including altamiza (feverfew), and hierba de Santa María (St. Mary's grass), manzanilla grande (large feverfew), manzanilla romana (Roman chamomile), mastranzo, matlali, and yerba santa. At the State of México; Otomí ethnia recognizes it as dhata manzanilla. The Náhuatlacas' native culture of Tlaxcala state is also known as caltemesha, and it is found distributed throughout the entire country, (Villaseñor and Espinosa, 1998). In traditional medicine in Denmark, T. parthenium is utilized in the prophylactic treatment of migraine, epilepsy, and convulsions, as well as a sedative and a sleep inducer (Jäger et al., 2006, 2009).

\footnotetext{
* Corresponding author.

E-mail address: estrarosa@hotmail.com (R. Estrada-Reyes).
} 
In Mexican traditional medicine, T. parthenium is used to relieve ailments, such as fevers, migraine, headache, rheumatoid arthritis, stomachache, toothache, and as an analgesic, anti-inflammatory, and antispasmodic agent. This species is also employed to treat culturebound syndromes such as susto (roughly translated as fear), espanto (nervousness), or quemados (burns) (Diccionario enciclopédico de la Medicina Tradicional Mexicana, 2009; Bourbonnais-Spear et al., 2007; Estrada-Reyes et al., 2014). Within this cross-cultural construction of illness, there is an association between beliefs of susto and depression. Susto has also been associated with social role stress and depressive symptoms (Weller et al., 2008) and espanto has been related with nervousness or nerves, to communicate anxiety and emotional distress (Mendenhall et al., 2012). Furthermore, although its etiology is an area of active research, American Psychiatry Association (DSMV, 2013) associates susto with mental disorders, including a number of anxiety and fear-related conditions (i.e., Post-Traumatic Stress Disorder [PTSD], anxiety disorder, major depressive disorders, somatoform disorders, and other specified neurotic disorders).

Phytochemical studies of this species have demonstrated a large number of secondary metabolites including sesquiterpene lactones, such as parthenolide, santamarin, and other potentially active constituents including flavonols such as santin, and flavonoid glycosides such as 6-hydroxykaempferol derivatives, quercetagetin, apigenin and apigenin 7-glucuronide, and luteolin, among others (Majdi et al., 2011; Long et al., 2003; Chávez and Chávez, 1999; Williams et al., 1999a and 1999b).

On the other hand, in humans, there are high levels of comorbidity between anxiety and depression disorders (Kessler et al., 2010; Kelsey and Collimore, 2014), that share neural pathways; thus, numerous neurotransmitters systems are involved in the underlying mechanisms of anxiolytic and antidepressant drugs.

GABA is the principal inhibitory neurotransmitter in the mammalian Central Nervous System (CNS) and plays an important role in epilepsy and anxiety (Olsen and DeLorey, 1999; Möhler, 2006; Treiman, 2001). Therefore, it is not surprising that modulation of GABAergic transmission comprises one of the main mechanisms for controlling these disorders (Morimoto et al., 2004; Sherif and Ahmed, 1995; Beleboni et al., 2004). Is widely known that anxiolytic drugs such as the Benzodiazepines (BDZ) act to enhance the effect of GABA at the $\mathrm{GABA}_{\mathrm{A}}$ receptor, even more so, some antidepressant derivatives of $\mathrm{BDZ}$, such as Alprazolam, not only induce anxiolytic actions, but also have antidepressant effects; thus, they are useful in the treatment of comorbid anxiety and depression.

The aim of this work was to investigate the anxiolytic- and antidepressant-like effects of an aqueous extract of $T$. parthenium in behavioral paradigms in mice. The main constituents of T. parthenium were determined by High-Performance Liquid ChromatographyElectroSpray Ionization-Mass Spectrometry (HPLC-ESI-MS) analysis.

The anxiolytic effect of $T$. parthenium was evaluated utilizing the Burying Behavior Test (BBT) and the Plus-Maze Test (PMT), and the results compared with the effects of Diazepam (DZ), and Alprazolam (ALP). The antidepressant-like effect of $T$. parthenium was evaluated with the Forced Swimming Test (FST) and compared with the effects of Fluoxetine (FLX) and ALP. The effects of T. parthenium on locomotor activity were evaluated in the Open Field Test (OFT).

We also explored the possible neurotransmission pathways that underlie $T$. parthenium actions using synergism with sub-effective doses of the GABAergic agonist, muscimol, with non-effective doses of $T$. parthenium. T. parthenium anxiolytic actions were blocked by coadministration of $T$. parthenium at $5 \mathrm{mg} / \mathrm{kg}$ with Picrotoxin, a GABAergic antagonist in the PMT. Finally, in independents experiments, T. parthenium antidepressant effects included enhancement with the coadministration of a $T$. parthenium non-effective dose in combination with a non-effective FLX or ALP dose in the FST, and their actions were blocked by the combination of $T$. parthenium effective doses with $p$ chlorophenylalanine (PCPA), a serotoninergic full antagonist.

\section{Materials and methods}

\subsection{Plant material}

Leaves of Tanacetum parthenium Asteraceae (before; Chrysanthemum parthenium) were collected in July 2014 in the Estado de México Municipality of Zinacantepec, Contadero de Matamoros (San José) México, in the yard of a private home $19^{\circ} 03^{\prime} 47^{\prime \prime} \mathrm{N} 99^{\circ} 54^{\prime} 47^{\prime \prime} \mathrm{W}$ altitude, $3073 \mathrm{~m}$ above sea level.

Botanical identification was carried out by Óscar HinojosaEspinosa, M. SC., and a sample was deposited in the Universidad Nacional Autónoma de México (UNAM) National Herbarium (voucher specimen number: MEXU1392990).

The aerial parts of Tanacetum parthenium were air-dried and finely ground and aqueous extracts were prepared at a ratio of $10 \mathrm{~g}$ of vegetal material per $90 \mathrm{~mL}$ of boiling distilled water and heated for $10 \mathrm{~min}$. The resulting extract was allowed to cool to room temperature, filtered, and dried in a Heto FD3 freezer dryer at $-50{ }^{\circ} \mathrm{C}$ and 0.01 $\mathrm{mBar}$, yielding $15.1 \%$ (1.51 g) of dried aqueous extract. The extract was stored $-4{ }^{\circ} \mathrm{C}$ until pharmacological assays or HPLC analyses were performed. To facilitate HPLC analysis, 20-mg aliquots of the aqueous extract were filtered through an OASIS Waters HLB 1 cc pre-column, eluted with $\mathrm{H}_{2} \mathrm{O}, \mathrm{H}_{2} \mathrm{O}-\mathrm{MeOH}$ mixtures (80:20, 50:50, and 20:80), $\mathrm{MeOH}$, and MeCN prior to HPLC analysis.

\subsubsection{Aqueous extract analysis by HPLC-ESI-MS}

The aqueous extract was analyzed by Aligent Technologies 1200 Series HPLC, utilizing a Millennium Chromatography Manager (464) system, with an Ultraviolet (UV) Detector of Diode (DAD) rearrangement (Waters 2996). Reverse-phase separation was conducted at room temperature, employing a Synergi Polar-RP 80 A $150 \times 2.00 \mathrm{~mm}$ I.D., with a $4-\mu \mathrm{m}$ particle size. The column was eluted at a flow-rate of $0.2 \mathrm{~mL} / \mathrm{min}$, in gradient mode, with mixtures of $\mathrm{MeOH} / \mathrm{H}_{2} \mathrm{O}(3: 97$; $5 \mathrm{~min}), \mathrm{MeOH} / \mathrm{H}_{2} \mathrm{O}(80: 20 ; 40 \mathrm{~min})$, and $\mathrm{H}_{2} \mathrm{O}(5 \mathrm{~min})$, for a total runtime of $50 \mathrm{~min}$. Elution was monitored at 220 and $254 \mathrm{~nm}$. HPLC was coupled to a Bruker Daltonics Esquire 6000 mass spectrometer.

An aliquot of the aqueous extract was filtered through C18 Waters Sep-Pak ${ }^{\circ}$ cartridges. Three fractions were obtained and injected into the HPLC system. Santin [1] and santamarin [2] were previously isolated from organic extracts of Tanacetum parthenium and served as standards. HPLC peaks were not corrected for response factors and are reported as relative percentage of the area (Estrada-Reyes et al., 2010). The identity and purity of the standards were confirmed by their physical and chemical properties and their spectral data $\left({ }^{1} \mathrm{H}\right.$ and ${ }^{13} \mathrm{C}$ Nuclear Magnetic Resonance [NMR] and MS), by means of comparison with results described in the literature.

\subsection{Pharmacological evaluations}

\subsubsection{Animals}

Adult male Swiss Webster mice (weighing 20-30 g) were obtained from the Vivarium at the Instituto Nacional de Psiquiatría Ramón de la Fuente Muñiz (INPRFM) Vivarium. All animals were housed eight per cage in a temperature-controlled $\left(20-21^{\circ} \mathrm{C}\right)$ room under inverted light:dark conditions ( $12 \mathrm{~h}: 12 \mathrm{~h}$, lights on at 22:00 h). All behavioral evaluations were performed between 10:00 and 14:00 h. Animals had ad libitum access to Purina rodent chow and water. The animals were managed in agreement with The General Principles of Laboratory Animal Care (NIH publication \#85-23, revised in 1985) and the 'Norma Oficial Mexicana' (NOM-062-ZOO-1999); furthermore, the experimental protocol was approved by the local ethical committee (NC093620.0).

\subsubsection{Drugs and dosage}

Doses are expressed as milligrams of drug per kilogram of Body Weight (BW) per mouse. T. parthenium (TP) $(0.5,1.0,5,10,20$, and 
$40 \mathrm{mg} / \mathrm{kg})$ was dissolved in saline $(0.9 \% \mathrm{NaCl})$ and administered orally (p.o.) by gastric gavage. Diazepam (DZ; 0.25, 0.5, 1 , or $2 \mathrm{mg} / \mathrm{kg}$ ), Muscimol (MUS; $0.5 \mathrm{mg} / \mathrm{kg}$ ),

Fluoxetine (FLX; $10 \mathrm{mg} / \mathrm{kg}), \quad p$-chlorophenylalanine (PCPA; $100 \mathrm{mg} / \mathrm{kg}$ ), Picrotoxin (PTX; $0.5 \mathrm{mg} / \mathrm{kg}$ ), and Alprazolam (ALP; $0.062,1.25,0.25$, and $0.5 \mathrm{mg} / \mathrm{kg}$ ) were purchased from SigmaAldrich, (Mexico City, Mexico). These were dissolved in saline and administered Intraperitoneally (IP). Control animals received the same volume of the vehicle (saline, $0.9 \% \mathrm{NaCl}$ ). For habituation, all mice received a daily p.o. or IP administration of saline for 5 days prior to treatment. Each treatment had its own control group, which was treated with the corresponding vehicle. Drugs were administered $30 \mathrm{~min}$ before the test, and all experiments were performed with independent groups of eight mice each.

2.2.2.1. Burying Behavior Test (BBT). Mice were individually tested in a cage with exactly the same dimensions as the home cages $(15 \times 24 \times 11 \mathrm{~cm})$, but with an electrified prod $(7 \mathrm{~cm}$ long) emerging from one of its walls, $2 \mathrm{~cm}$ above the bedding material of fine sawdust. Each time the animal touched the prod, the former received an electric shock of $0.3 \mathrm{~mA}$. The source of the shock was a constant current shocker (direct current apparatus, manufactured by Eng. Salvador Almanza, Bioengineering Department, INPRFM). The prod remained electrified throughout the test. Immediately after the placement of the animal in the cage, its behavior was recorded for $10 \mathrm{~min}$. Once the animal received the first shock, it typically moved toward the prod, recognizing it as an aversive stimulus. The animal then sprayed and pushed a pile of bedding material ahead with rapid alternating movements of its forepaws. The parameters registered in this anxiety test were burying behavior latency (time, in sec, from the first shock to the display of the burying behavior) and cumulative burying behavior (cumulative time, in sec, that the animals spend burying the prod). In this test, a decrease in cumulative burying behavior is interpreted as a reduction in anxiety (Pinel and Treit, 1978; Treit, 1985; De Boer and Koolhaas, 2003; López-Rubalcava et al., 2006). An increase in burying behavior latency is considered to reflect decreased reactivity (the readiness of the animal to respond to a certain condition).

2.2.2.2. Elevated Plus-Maze Test (PMT). This model has been widely validated for measuring anxiolytic-like effects in rodents (Lister, 1987). The apparatus consisted of two opposite open arms $(30 \times 8 \mathrm{~cm})$, intersected (center platform) by two closed arms of the same dimensions, with 19-cm-high walls. The arms were connected to an $8 \times 8 \mathrm{~cm}$ central square. The apparatus was elevated $55 \mathrm{~cm}$ above the floor, in a dimly illuminated room. Mice were placed individually in the center of the plus-maze, facing an open arm. During the 5-min test, the time spent in each arm was measured. The conventional spatialtemporal measurements comprised the number of entries (all paws on open or closed arms and expressed as percentage of total entries), Time spent in the Open Arms (TOA) was expressed as a percentage of the Time spent in the Open Arms (TOA), \% TOA=TOA/TCA $\times 100$ (Time spent in Closed Arms; TCA), \% Open Arm Entries (\% OAE), OAE=Open Arm Entries/[Closed Arm Entries+Open Arm Entries] $\times 100$ and time on the Central Platform $(\mathrm{TC})=[\mathrm{TOA}+\mathrm{TBC}]-300$; (300 s=test time, in such a way that $\mathrm{TOA}+\mathrm{TCA}+\mathrm{TC}=300 \mathrm{~s}$ ). Percentage of time and number of entries in the open arms are considered indices of anxiety-level behavior (Lister, 1987; Rocha et al., 2002). Ethological behaviors, such as time spent on the Central Platform (CP) and number of head dipping was also registered.

2.2.2.3. Forced Swimming Test (FST). Mice were individually placed into glass cylinders (height: $21 \mathrm{~cm}$, diameter; $14.5 \mathrm{~cm}$ ) containing $15 \mathrm{~cm}$ of water at $23 \pm 1^{\circ} \mathrm{C}$. All animals were forced to swim for a 15-min period (pre-test), followed by a 3-min swimming session (test) $24 \mathrm{~h}$ later. Total immobility time was measured in sec. Immobility behavior was scored when the mouse remained floating and treading water just sufficiently to keep its nose above water. After the swimming sessions, the mice were removed from the cylinder and carefully dried, placed in heated cages for $20 \mathrm{~min}$, and then returned to their home cages. All experimental sessions were videotaped and later scored by an observer who was unaware of the pharmacological treatments (Porsolt et al., 1977a, 1977b; Martínez-Vázquez et al., 2012).

2.2.2.4. Open Field Test (OFT). To discard possible unwanted or nonspecific side effects of drug treatments on locomotor activity, all treatments studied in the anxiety and depression paradigms were analyzed in the Open Field Test (OFT). The OFT system (LE8825, Panlab InfraRed (IR) Harvard apparatus) consisted of Perspex panels $(45 \times 45 \mathrm{~cm}, 2.2-\mathrm{cm}$ thick) in a 2-Dimensional (2D) (X and $\mathrm{Y}$ axes) square frame, a frame support, and a control unit. Each frame counted employed $16 \times 16$ infrared beams for optimal subject detection. The frames were controlled by independent control units. Acti Track software was utilized to analyze the animals' trajectories. Data were exported to a computer for analysis. The number of times the animal entered each square (counts/10 min) was recorded. A change in counts was considered an alteration in the locomotor activity of the experimental subject, produced by the drugs (Estrada-Reyes et al., 2014).

To explore the participation of the GABAergic system in the anxiolytic- and antidepressant-like actions of T. parthenium, the following experiments were performed.

Experiment I: PTX at $0.5 \mathrm{mg} / \mathrm{kg}$ was administered simultaneously with $T$. parthenium $(5 \mathrm{mg} / \mathrm{kg} ;-30 \mathrm{~min}$ ) to mice, followed by testing in the PMT.

Experiment II: One group was treated with a non-effective dose of the $\mathrm{GABA}_{\mathrm{A}}$ agonist muscimol (MUS; $0.5 \mathrm{mg} / \mathrm{kg}$ ) jointly with a threshold dose of $T$. parthenium $(0.5 \mathrm{mg} / \mathrm{kg})$, insufficient to induce anxiolytic effects. After $30 \mathrm{~min}$, the mice were subjected to the PMT to determine the possible synergic effect.

Experiment III: Sub-threshold doses of alprazolam (ALP, $0.03 \mathrm{mg} / \mathrm{kg}$ ), an anxiolytic, triazolobenzodiazepine (thiazolo-BDZ), and $T$. parthenium $(0.5 \mathrm{mg} / \mathrm{kg})$ were administered together to mice that, after $30 \mathrm{~min}$, were subjected to the PMT.

To determine whether antidepressant drugs are able to block or enhance the antidepressant-like effects of T. parthenium in the forced swimming paradigm, experiments to antagonize and synergize the drug were designed.

Experiment I: A group was treated with T. parthenium at a single sub-effective dose $(5 \mathrm{mg} / \mathrm{kg})$ in combination with a sub-threshold dose of Fluoxetine (FLX; $10 \mathrm{mg} / \mathrm{kg}$ ), a serotonin reuptake inhibitor. Thirty min later the mice were tested in the FST.

Experiment II: Two independent groups of eight animals each were pretreated with PCPA $(100 \mathrm{mg} / \mathrm{kg}$, an inhibitor of serotonin synthesis), and a third group was given only the vehicle, once a day, for 4 consecutive days (Cassani et al., 2014). After the last administration of PCPA, one group was treated with $T$. parthenium $(20 \mathrm{mg} / \mathrm{kg}$, p.o.) and the remaining groups only received vehicle. Then, all mice were tested in the FST 30 min later.

2.2.2.5. Statistical analysis. Results are present as the mean \pm Standard Error of the Mean (SEM). Data were analyzed with Kruskal-Wallis ANalysis Of VAriance (ANOVA) on ranks ${ }^{*} p<0.05$, ${ }^{* *} p<0.01$, and ${ }^{* * *} p<0.001$ ), followed by the Mann-Whitney rank sum test. The SigmaPlot ver. 12.5 statistical software program was used to make the graphics and to conduct the analysis. 
<smiles>COc1ccc(-c2oc3cc(O)c(OC)c(O)c3c(=O)c2OC)cc1</smiles>

$\mathrm{RT}=33.6 \mathrm{~min}, \mathrm{C}_{18} \mathrm{H}_{16} \mathrm{O}_{7}$ Exact mass 344.3154<smiles>C=C1C(=O)O[C@H]2C1CCC1(C)C(O)CC=C(C)[C@H]21</smiles>

santamarine [2]
$\mathrm{RT}=30.3 \mathrm{~min}, \mathrm{C}_{15} \mathrm{H}_{20} \mathrm{O}_{3}$ Exact mass 248.1412

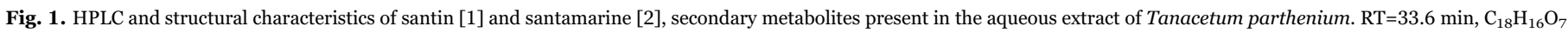
$\mathrm{RT}=30.3 \mathrm{~min}, \mathrm{C}_{15} \mathrm{H}_{20} \mathrm{O}_{3}$ Exact mass 344.3154 Exact mass 248.1412.

\section{Results}

\subsection{Chemical Analysis of aqueous extract of T. parthenium}

Santin and santamarine were isolated from the organic extracts and utilized as standards in the HPLC-MS analysis. Sesquiterpene lactones, such as parthenolide or canin, were not isolated from the organic extract and were not identified in the aqueous extract of T. parthenium. The aqueous extract of $T$. parthenium was found to contain the flavone santin [1] at 7.4\% (relative abundance), and santamarine [2] (an isomeric form of parthenolid), a sesquiterpene lactone, was found at $4 \%$ (Fig. 1). It has been described that parthenolid is present only in trace in Mexican samples of feverfew (Hausen, 1981).

The BBT was employed to measure the anxiolytic effects of different doses of $T$. parthenium aqueous extract. As presented in Table $1, T$. parthenium at 5,10 , and $20 \mathrm{mg} / \mathrm{kg}$ decreased the cumulative time that animals spent burying the prod and increased burying behavior latency in a dose-dependent fashion; this effect was similar to the results produced by DZ at $0.5 \mathrm{mg} / \mathrm{kg}$. The one-way ANOVA on ranks revealed that for the two parameters analyzed (cumulative burying behavior and burying behavior latency), both $T$. parthenium and DZ exhibited statistically significant differences with respect to the control group $(\mathrm{H}=29.420 ; \mathrm{df}=5 ; p \leq 0.001)$.

\subsection{Effects of increasing doses of $\mathrm{T}$. parthenium on the PMT are depicted in Fig. 2}

The acute treatment with $T$. parthenium at $0.5,1,5$, and $10 \mathrm{mg} / \mathrm{kg}$

Table 1

Effect of TP and DZ $(0.5 \mathrm{mg} / \mathrm{kg})$ on the burying latency time and burying cumulative time in the Burying Behavior Test.

\begin{tabular}{lll}
\hline Treatment $(\mathrm{mg} / \mathrm{kg})$ & Burying latency time $(\mathrm{s})$ & Burying cumulative time $(\mathrm{s})$ \\
\hline Control & $32.90 \pm 5.99$ & $76.44 \pm 10.92$ \\
DZ 0.5 & $35.97 \pm 4.12$ & $36.79 \pm 5.68^{* * * *}$ \\
TP 1 & $28.90 \pm 6.36$ & $70.62 \pm 11.05$ \\
TP 5 & $26.43 \pm 12.56$ & $31.12 \pm 4.32^{* * *}$ \\
TP 10 & $38.43 \pm 11.45$ & $9.28 \pm 4.32^{* * * *}$ \\
TP 20 & $34.44 \pm 7.06$ & $6.71 \pm 2.51^{* * * *}$ \\
& $\mathrm{H}=10.1, \mathrm{df}=5, \mathrm{p}=0.072$ & $\mathrm{H}=29.4, \mathrm{df}=5, \mathrm{p} \leq 0.001$
\end{tabular}

Effect of treatment with single dose (p.o.) of TP at 1, 5, 10, 10, and $20 \mathrm{mg} / \mathrm{kg}$ and single treatment with diazepam (DZ $0.5 \mathrm{mg} / \mathrm{kg}$ ), by intraperitoneally via in the BBT in mice. All results are expressed as the mean \pm SEM of 8 animals. Comparisons were made using the Kruskal-Wallis analysis of variance based on rank, followed by the Mann-Whitney- $U$ test.

${ }^{* * *} p<0.001$

$$
\text { *** } p<0.01 \text {. }
$$

produced a significant increase in both \% of time spent in the open arms $(\mathrm{H}=30.22 ; \mathrm{df}=6 ; p \leq 0.001)$, and percentage of open-arm entries $(\mathrm{H}=32.75 ; \mathrm{df}=6 ; p \leq 00.1)$ compared with the vehicle-treated group. Similarly, mice treated with DZ at doses ranging from 0.25 to $2.0 \mathrm{mg} /$ $\mathrm{kg}$ produced a significant increase in \% of time spent in the open arms in a dose-dependent manner $(\mathrm{H}=32.292 ; \mathrm{df}=4 ; p \leq 0.001)$ and percentage of open-arm entries $(\mathrm{H}=28.530 ; \mathrm{df}=4 ; p \leq 0.001)$, and mice treated with ALP at 0.25 and $0.5 \mathrm{mg} / \mathrm{kg}$ also spent significantly more time on the open arms and presented an increased percentage of entries on the open arms. At higher doses (20 and $40 \mathrm{mg} / \mathrm{kg}$ ), $T$. parthenium did not produce changes compared with the vehicle-treated group.

Other parameters measured in the PMT are illustrated in Table 2. Animals treated with $T$. parthenium $(1,5,10,20$, and $40 \mathrm{mg} / \mathrm{kg}$ ) also demonstrated increases in time spent in head dipping $(\mathrm{H}=20.410$; $\mathrm{df}=6 ; p \leq 0.01$ ), while time spent on the $\mathrm{CP}$ only increased significantly with $T$. parthenium at $40 \mathrm{mg} / \mathrm{kg}(\mathrm{H}=13.6 ; \mathrm{df}=6 ; p \leq 0.03)$. Likewise, total arm entries differed only at major $T$. parthenium doses (20 and $40 \mathrm{mg} / \mathrm{kg}$ ) from those of the vehicle-treated group.

In the FST, as presented in Fig. 3, T. parthenium at 10-, 20-, and $40-\mathrm{mg} / \mathrm{kg}$ doses significantly reduced immobility time with respect to the control group $(\mathrm{H}=33.590 ; \mathrm{df}=5 ; p \leq 0.001)$. In a similar manner, $\mathrm{ALP}$ at 0.03 and $0.062 \mathrm{mg} / \mathrm{kg}$ significantly reduced immobility time compared with the control group $(\mathrm{H}=22.10 ; \mathrm{df}=2 ; p \leq 0.001)$. In contrast with $T$. parthenium and ALP, acute FLX administration was not able to modify the immobility behavior, this fact in concordance with those previously reported (Martínez-Vázquez et al., 2012).

All of the drugs were tested in the OFT, and the effects of $T$. parthenium on the locomotor and exploratory activity of the experimental animals are exhibited in Table 3 . T. parthenium did not modify the count number $(\mathrm{H}=19.18 ; \mathrm{df}=6 ; p=0.51)$ or alter the rearing number $(\mathrm{H}=12, \mathrm{df}=6, \mathrm{p}=0.06)$ compared with the control group, $T$. parthenium did not alter any exploratory parameters in the OFT. In addition, no drug modified the ambulatory behavior of the animals tested (data not shown).

\subsection{Effects of co-administration of T. parthenium plus PTX and plus ALP in the PMT}

To determine whether the GABAergic antagonist Picrotoxin could block the anxiolytic actions of T. parthenium, an anxiolytic dose of $T$. parthenium $(5 \mathrm{mg} / \mathrm{kg}$ ) was jointly administered with PTX at $0.5 \mathrm{mg} /$ $\mathrm{kg}$; after $30 \mathrm{~min}$, the experimental animals were subjected to the PMT. As can be observed in Table 4, treatment with PTX alone at $0.5 \mathrm{mg} / \mathrm{kg}$ did not produce any effect in comparison with the control group, while this same PTX dose was able to block the anxiolytic effect produced by T. parthenium when the two were jointly administered. In addition, the T. parthenium /PTX combination reduced the \% of time spent in open arms by $70 \%$ with respect to the control group. 

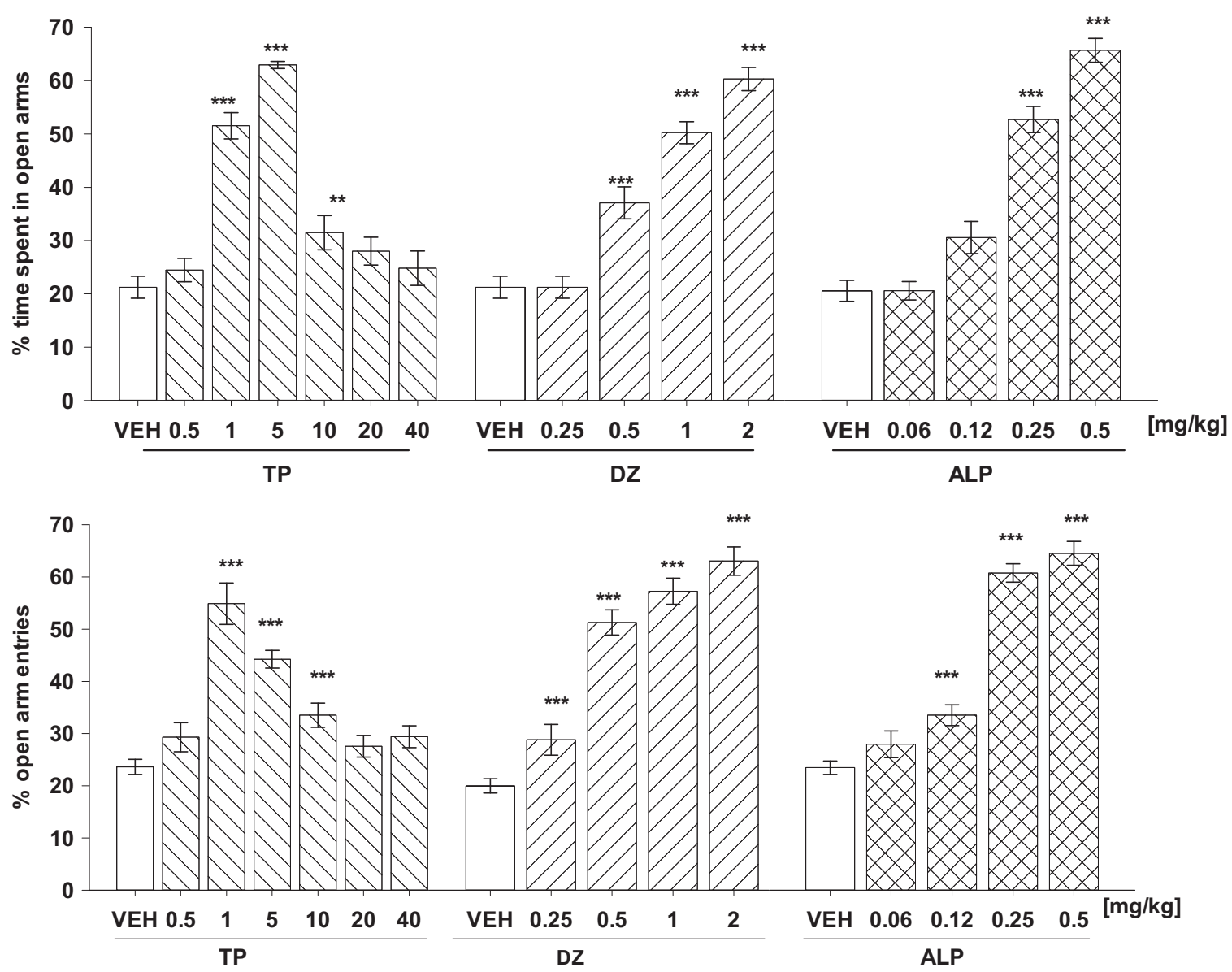

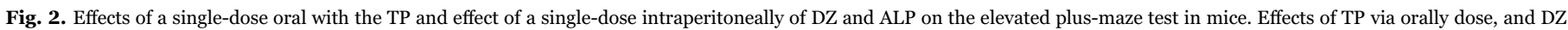

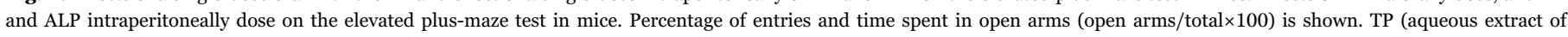

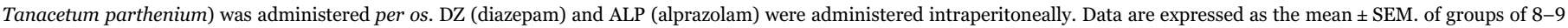

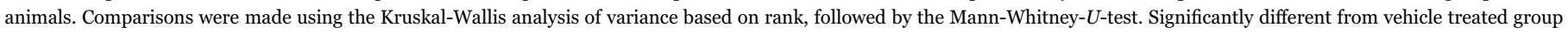
${ }^{*} \mathrm{p} \leq 0.05,{ }^{* *} \mathrm{p} \leq .01$, and ${ }^{* * *} \mathrm{p} \leq 0.001$.

Table 2

Effects of a single-dose treatment with the TP, DZ, and ALP upon the behavioral parameters recorded in the elevated plus-maze test in mice.

\begin{tabular}{|c|c|c|c|c|c|}
\hline Treatment (mg/kg) & TCA & \%TCA & Total arm entries & central platform time (s) & time spent in head dipping (s) \\
\hline VEHICLE & $176.4 \pm 11.5$ & 75.5 & $17.37 \pm 1.1$ & $66.2 \pm 10.9$ & $13 \pm 0.8$ \\
\hline ТР0.5 & $138.9 \pm 10.5^{* * *}$ & 70 & $19.25 \pm 1.5$ & $61.5 \pm 10.8$ & $14.1 \pm 1.1$ \\
\hline TP1 & $106 \pm 11.6^{* * *}$ & 49 & $18.6 \pm 1.6$ & $83.5 \pm 11.2$ & $27.7 \pm 3.5^{* * * *}$ \\
\hline TP 5 & $127 \pm 6^{* * * * *}$ & 40 & $20.8 \pm 1.3$ & $79.28 \pm 8.9$ & $23.3 \pm 2.2^{* * * *}$ \\
\hline TP10 & $162.2 \pm 11.2$ & 69 & $19.3 \pm 0.7$ & $63.2 \pm 6.9$ & $17 \pm 3.3^{* * *}$ \\
\hline TP20 & $143.4 \pm 7.7$ & 71 & $24.2 \pm 1.2^{* * * *}$ & $99.1 \pm 10.8$ & $18 \pm 2.3^{* * *}$ \\
\hline \multirow[t]{2}{*}{ TP40 } & $152.9 \pm 8.7$ & 76 & $22.2 \pm 1.65^{* * *}$ & $98.8 \pm 5.6^{*}$ & $16 \pm 2.3^{* * *}$ \\
\hline & $\mathrm{H}=18.36, \mathrm{df}=6 . \mathrm{P}=0.005$ & & $H=17.78, d f=6, p=0.007$ & $\mathrm{H}=13.60, \mathrm{df}=6, \mathrm{p} \leq 0.03$ & $\mathrm{H}=20.41, \mathrm{df}=6, \mathrm{p}=0.002$ \\
\hline VEHICLE & $216.4 \pm 10.9$ & 79 & $16.3 \pm 1.2$ & $66.3 \pm 6.9$ & $10.25 \pm 1$ \\
\hline DZ 0.25 & $143 \pm 8^{* * * * *}$ & 45 & $15.1 \pm 1.3$ & $117.6 \pm 6.2^{* * * *}$ & $11.87 \pm 1$ \\
\hline DZ 0.5 & $129.3 \pm 5^{* * * *}$ & 63 & $19.3 \pm 0.8$ & $93.9 \pm 6.5^{*}$ & $14.3 \pm 1$ \\
\hline DZ 1 & $110 \pm 5.7^{* * *}$ & 58 & $19 \pm 2.1$ & $77.31 \pm 16$ & $17.5 \pm 1.8$ \\
\hline \multirow[t]{2}{*}{$\mathrm{DZ} 2$} & $89.3 \pm 7.1^{* * *}$ & 39 & $19.2 \pm 2$ & $72.2 \pm 11.7$ & $22 \pm 2.1$ \\
\hline & $30.06, \mathrm{df}=4, \mathrm{p} \leq 0.001$ & & $\mathrm{H}=6.41, \mathrm{df}=4, \mathrm{p} \leq 0.17$ & $\mathrm{H}=21.8, \mathrm{df}=4, \mathrm{p} \leq 0.001$ & $\mathrm{H}=18.35, \mathrm{df}=4, \mathrm{p} \leq 0.001$ \\
\hline VEHICLE & $178 \pm 10.4$ & 76 & $16.7 \pm 1$ & $65.4 \pm 9.6$ & 13. \pm 0.7 \\
\hline ALP 0.06 & $173.3 \pm 5.1$ & 79 & $14.5 \pm 1.3$ & $80.9 \pm 7.4$ & $10.2 \pm 1.4$ \\
\hline ALP 0.12 & $188.2 \pm 11.9$ & 80 & $14.1 \pm 2.1$ & $63.9 \pm 7.5$ & $12.6 \pm 1.7$ \\
\hline ALP 0.25 & $66.7 \pm 8.9^{* * * *}$ & 56 & $21 \pm 1.9$ & $98.9 \pm 10.7$ & $25.2 \pm 1.8$ \\
\hline \multirow[t]{2}{*}{ ALP 0.5} & $116.1 \pm 7.11^{* * * *}$ & 67 & $31.6 \pm 2.3^{* * * *}$ & $54.3 \pm 9$ & $29.8 \pm 2.5$ \\
\hline & $\mathrm{H}=32.32, \mathrm{df}=4, \mathrm{p} \leq 0.001$ & & $\mathrm{H}=24.1, \mathrm{df}=4, \mathrm{p} \leq 0.001$ & $\mathrm{H}=6.4, \mathrm{df}=4, \mathrm{p} \leq 0.17$ & $\mathrm{H}=28.34, \mathrm{df}=4, \mathrm{p}=\leq 0.001$ \\
\hline
\end{tabular}

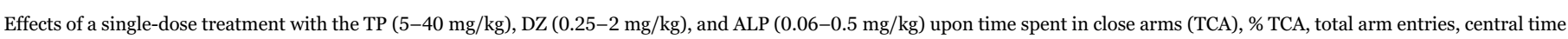

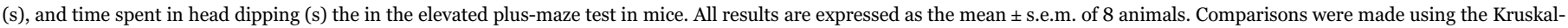
Wallis analysis of variance based on rank, followed by the Mann-Whitney- $U$-test.

${ }^{* * *} p<0.01$.

$p<0.001$. 

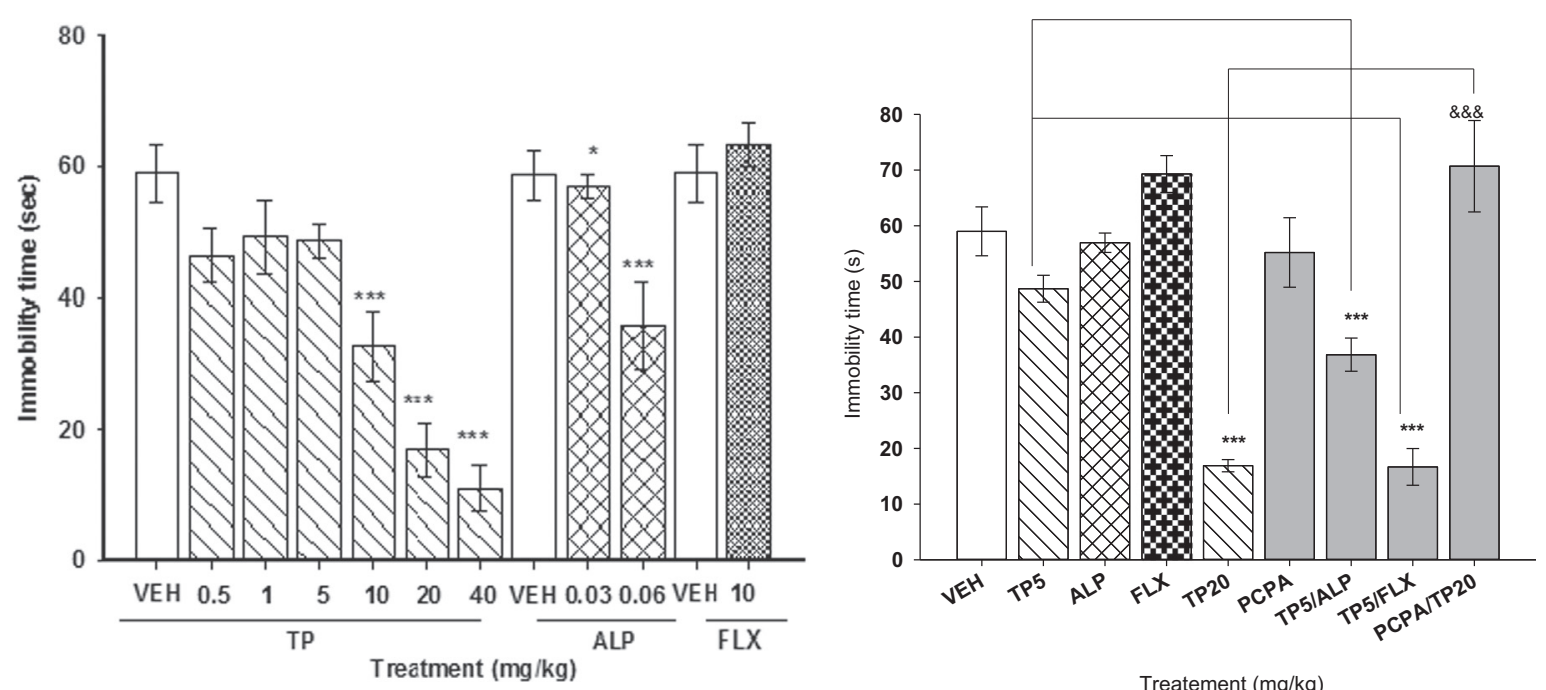

Treatement $(\mathrm{mg} / \mathrm{kg})$

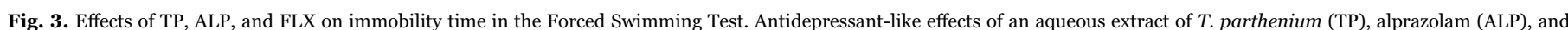

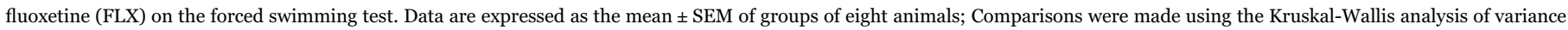
based on rank, followed by the Mann-Whitney- $U$-test. Significantly different from vehicle treated group (VEH) ${ }^{*} \mathrm{p} \leq 0.05$ and ${ }^{* * *} \mathrm{p} \leq 0.001$.

Table 3

Effect of aqueous extract of leaves of Tanacetum parthenium (TP) on the ambulatory activity of mice in the OFT.

\begin{tabular}{lll}
\hline Treatment $(\mathrm{mg} / \mathrm{kg})$ & $\mathrm{n}$ & $\begin{array}{l}\text { Count number } / 5 \mathrm{~min} \\
\text { mean } \pm \text { s.e.m. }\end{array}$ \\
\hline control & 7 & $42.85 \pm 4.96$ \\
TP 0.5 & 8 & $33.00 \pm 2.98$ \\
TP 1 & 8 & $55.62 \pm 4.53$ \\
TP 5 & 8 & $47.71 \pm 3.57$ \\
TP 10 & 8 & $37.12 \pm 3.29$ \\
TP 20 & 8 & $36.62 \pm 1.99$ \\
TP 40 & 8 & $39.00 \pm 1.75$ \\
& & $\mathrm{H}=2.87, \mathrm{df}=6, \mathrm{p}=0.579$ \\
control & & $50.75 \pm 2.78$ \\
DZ 0.25 & 8 & $58.12 \pm 5.85$ \\
DZ 0.5 & 8 & $59.50 \pm 5.64$ \\
DZ 1.0 & 8 & $46.87 \pm 5.91$ \\
DZ 2.0 & 8 & $44.25 \pm 6.16^{*}$ \\
& 8 & $\mathrm{H}=19.18, \mathrm{df}=4, \mathrm{p}=0.04$ \\
\hline
\end{tabular}

Results are expressed as mean \pm SEM statistical comparisons were made between the saline-treated group and the experimental groups using a Kruskal-Wallis One Way Analysis of Variance on Ranks, followed by the Mann-Whitney Rank Sum Test ( $\mathrm{p}^{*}<$ 0.05).

In this same paradigm, the combination of a sub-threshold dose of T. parthenium $(0.5 \mathrm{mg} / \mathrm{kg})$ and an ineffective dose of ALP $(0.12 \mathrm{mg} /$ $\mathrm{kg}$ ) were evaluated. Our results revealed that the combination of $T$. parthenium /ALP at a non-effective dose, significantly increased time and percentage spent in open arms and reduced time spent in closed arms in the PMT, compared with the control group (Table 4).

\subsection{Effects of co-administration of T. parthenium plus ALP, plus FLX, and plus PCPA in the FST}

To determine whether ALP could enhance the antidepressant-like actions of $T$. parthenium, a combination of non-effective doses of $T$. parthenium $(5 \mathrm{mg} / \mathrm{kg})$ and ALP $(0.03 \mathrm{mg} / \mathrm{kg})$ were co-administered and the effect was evaluated in the FST. As demonstrated in Fig. 3, ALP, a benzodiazepine-type antidepressant drug at $0.03 \mathrm{mg} / \mathrm{kg}$, in combination with $5 \mathrm{mg} / \mathrm{kg}$ of $T$. parthenium, providing an antidepressant-like effect with a statistically significant difference in the MannWhitney test: $\mathrm{T}=97 ; n=8$, and $p \leq 0.001$. Likewise, the combination of threshold doses of $T$. parthenium with a single, non-effective dose of
Table 4

Effects of the combination of TP $(0.5 \mathrm{mg} / \mathrm{kg})$ plus PTX $(0.5 \mathrm{mg} / \mathrm{kg}), \mathrm{TP}(0.5 \mathrm{mg} / \mathrm{kg})$ plus ALP $(0.12 \mathrm{mg} / \mathrm{kg})$, and TP $(0.5 \mathrm{mg} / \mathrm{kg})$ plus MUS $(0.5 \mathrm{mg} / \mathrm{kg})$ in plus-maze test.

\begin{tabular}{llll}
\hline $\begin{array}{l}\text { Treatment } \\
(\mathrm{mg} / \mathrm{kg})\end{array}$ & $\begin{array}{l}\text { Time spent in open } \\
\text { arms (s) }\end{array}$ & $\begin{array}{l}\text { Time spent in close } \\
\text { arms (s) }\end{array}$ & $\begin{array}{l}\text { \% Time spent in } \\
\text { open arms (s) }\end{array}$ \\
\hline control & $57.2 \pm 4.3$ & $176.4 \pm 11.5$ & $21.2 \pm 2.0$ \\
TP 0.5 & $59.5 \pm 3.9$ & $138.9 \pm 10.5$ & $30.4 \pm 2.2$ \\
PTX 0.5 & $47.3 \pm 2.6$ & $211.1 \pm 7.3^{++}$ & $18.4 \pm 1.3$ \\
ALP 0.12 & $43.3 \pm 6.0$ & $194.1 \pm 11.7$ & $18.5 \pm 2.8$ \\
TP 5/PTX 0.5 & $13.0 \pm 2.0^{++}$ & $231.9 \pm 8.1^{+++}$ & $5.3 \pm 0.7^{+++}$ \\
TP 0.5/ALP & $90.7 \pm 9.28$ & $102.3 \pm 7.8^{* * * *}$ & $46.7 \pm 2.9^{* * * *}$ \\
$\quad 0.12$ & & $144.0 \pm 9.1$ & $31.5 \pm 3.6$ \\
MUS 0.5 & $66.1 \pm 4.30$ & $107.0 \pm 17.9^{* * * *}$ & $54.8 \pm 5.6^{* * * *}$ \\
MUS 0.5/TP & $124.8 \pm 12.9^{* * * *}$ & & \\
$\quad 0.5$ & $\mathrm{H}=61.51, \mathrm{df}=9$, & $\mathrm{H}=49.02, \mathrm{df}=9$, & $\mathrm{H}=59.11, \mathrm{df}=9$, \\
& $\mathrm{p} \leq 0.001$ & $\mathrm{p} \leq 0.001$ & $\mathrm{p} \leq 0.001$ \\
\hline
\end{tabular}

Effect of co-administration of TP at $0.5 \mathrm{mg} / \mathrm{kg}$ (p.o.) with picrotoxin (PTX; $5 \mathrm{mg} / \mathrm{kg}$, IP), TP $(0.5 \mathrm{mg} / \mathrm{kg})$ with alprazolam (ALP; $0.12 \mathrm{mg} / \mathrm{kg}$, IP), and TP $(0.5 \mathrm{mg} / \mathrm{kg}$, p.o.) with muscimol (MUS, $0.5 \mathrm{mg} / \mathrm{kg}$, IP). All results are expressed as the mean $\pm \mathrm{SEM}$ of 8 animals. Comparisons were made using the Kruskal-Wallis analysis of variance based on rank, followed by the Mann-Whitney-U-test: ${ }^{* *} \mathrm{p}<0.01\left({ }^{*}\right.$ significant increase with respect to control group), (+ significant decrease with respect to control group). ${ }^{++} \mathrm{p}<0.01$.

$$
{ }^{+++} \mathrm{p}<0.001 \text {. }
$$$$
{ }^{* * *} p<0.001 \text {. }
$$

FLX $(10 \mathrm{mg} / \mathrm{kg})$ facilitated the antidepressant actions of $T$. parthenium ( $\mathrm{T}=89 ; n=8 ; p=0.001$ ) compared with the control-treated group.

We explored the involvement of the 5-HT system in the antidepressant-like effect of $T$. parthenium. For this purpose, 5-HT was depleted by means of the tryptophan hydroxylase inhibitor $p$-chlorophenylalanine (PCPA, $100 \mathrm{mg} / \mathrm{kg}$, i.p., 4 days) prior to treatment with the $T$. parthenium effective dose $(20 \mathrm{mg} / \mathrm{kg})$. The consequent results showed that PCPA blocked the anti-immobility effect of T. parthenium, because the group treated with $T$. parthenium plus PCPA did not exhibit a significant difference with respect to the control group (Mann-Whitney test: $\mathrm{T}=51 ; n=8 ; p=0.08$ ).

\section{Discussion}

Anxiety and depression disorders are highly prevalent conditions and entertain high levels of comorbidity (Kessler et al., 2010; Kelsey and Collimore, 2014). Individuals affected by both anxiety and 
depressive disorders concurrently have generally exhibited greater levels of functional impairment, reduced quality of life, and poorer treatment outcomes compared with individuals with only one of these disorders (Lamers et al., 2011).

As mentioned previously, Tanacetum parhtenium is employed by several medical conditions, although to date, few in vivo experiments have been carried out. In the present work and, to our knowledge for the first time, we studied the effects of the aqueous extract of $T$. parhtenium on the Central Nervous System (CNS).

One of main purposes of the present study was to analyze the anxiolytic-like effects of the aqueous extract of $T$. parthenium. To allow for this, the effects of $T$. parthenium were evaluated in two predictive animal models of anxiety. In the first assay, experimental anxiety values were determined employing the defensive burying behavior test; this is a conflict model largely validated for the study of both anxiolytic and anxiogenic drugs (Treit, 1985; López-Rubalcava et al., 2006). Our results revealed that the aqueous extract of $T$. parthenium at 5,10 , and $20 \mathrm{mg} / \mathrm{kg}$ produced a significant dose-dependent reduction compared with the control group in burying accumulative time, similar to the effects of Diazepam (DZ). It has been reported that compounds with anxiolytic actions decrease burying behavior, conjointly with buryingtime latency. Some authors have considered that this behavior is the animals' reactivity in an inverse manner and indicate that classic anxiolytics such as Benzodiazepines (BDZ) decrease reactivity, (LópezRubalcava et al., 2000). It is noteworthy that, herein, the decrease in burying behavior was not accompanied by an increase in burying behavior latency; thus, unlike DZ, T. parthenium clearly produced an anxiolytic-like effect without affecting animal reactivity. The anxiolytic effect of $T$. parthenium was also evaluated in the elevated Plus-Maze Test (PMT) (Lister, 1987; López-Rubalcava et al., 2006). The anxiolytic-like effect of TP was indicated by a significant increase in both entry number and time spent in open arms. These responses were observed at lower doses of $0.5-10 \mathrm{mg} / \mathrm{kg}$, achieving best effect at $5-$ and $10-\mathrm{mg} /$ $\mathrm{kg}$ doses. Frequency of entries is the natural spatiotemporal index of anxiety; it is reduced by anxiolytic drugs such as DZ and can be increased by anxiogenic drugs such as picrotoxin (PTX) (LópezRubalcava et al., 2000). In agreement with these findings, we found that $T$. parthenium demonstrated an anxiolytic profile similar to that of this antianxiety drug. Reduction of time spent on the Central Platform (CP) comprises another index of a reduced "decision-making" (hesitant behavior) behavior. Both parameters are accepted as reliable indicators of anxiety and fearfulness (Rocha et al., 2002). T. parthenium at any dose did not alter time spent on $\mathrm{CP}$ or in total arm entries. These observations also indicate that the anxiolytic-like effect of $T$. parthenium is selective and is not associated with a general stimulation of locomotor activity as a consequence of exposure to a novel environment. These facts were also confirmed by Open Field Test (OFT) results, which did not show any change in the locomotor activity of mice treated with $T$. parthenium. The anxiolytic effects induced by in the PMT were similar to those produced by DZ, an anxiolytic and sedative BDZ that acts as a positive allosteric modulator of the GABA at the BDZ site. Additionally, T. parthenium actions were also compared with those induced with alprazolam (ALP), a full agonist to the $\mathrm{GABA}_{\mathrm{A}}$ receptor (Rang et al., 1996; Hascoet and Bourin, 1997) that, in addition to its anxiolytic effects produces antidepressant effects. Thus, the three drugs demonstrated a similar anxiolytic effect, with ALP that of greatest pharmacological potency.

To explore the possible involvement of the GABAergic neurotransmitter system in the anxiolytic actions of $T$. parthenium, we conducted independent synergic experiments in which non-effective doses of $T$. parthenium $(0.5 \mathrm{mg} / \mathrm{kg})$ and sub-threshold doses of MUS $(0.5 \mathrm{mg} / \mathrm{kg})$ or ALP $(0.12 \mathrm{mg} / \mathrm{kg})$ were jointly administered. Our results revealed that the anxiolytic-like effect of $T$. parthenium in the PMT was enhanced with both concomitant administration of $T$. parthenium with MUS as well as with ALP. Furthermore, PTX is a non-competitive antagonist of the $\mathrm{GABA}_{\mathrm{A}}$ receptor that specifically acts at a site associated with the chloride channel preventing the inhibitory action of GABA, which increase anxiety levels (Petty et al., 1995). In this study, this drug was able to completely block the actions of $T$. parthenium in the PMT. It could be concluded that $T$. parthenium interacts with this neurotransmitter system to mediate its anxiolyticlike actions or $T$. parthenium contains compounds that facilitate GABAergic transmission. In this regard, the anxiolytic actions of numerous flavonoid compounds have been described (Estrada-Reyes et al., 2012; 2014); thus, it is likely that santin [1] could be contributing to the actions of $T$. parthenium. In addition, these results are consistent with those previously reported in an in vitro assay (Jäger et al., 2009). Taken together, these results suggest that T. parthenium interacts with the $\mathrm{GABA}_{\mathrm{A}}$ receptor, probably at $\mathrm{GABA}_{\mathrm{A}}$ receptor subtypes, in binding sites different from those at classical BDZ effects, produce anxiolytic effects. However, it is necessary to conduct specific studies to determine the specific target.

On the basis of $T$. parthenium in traditional medicine, another purpose was evaluated in this study of its antidepressant-like action in the Forced Swimming Test (FST) in mice. The FST induces a state of immobility in animals facing an inescapable situation of swimming; such immobility behavior has been hypothesized to reflect hopelessness, which may in turn reflect an aspect observed in depressive disorders in humans. Thus, the antidepressant-like activity of a drug is expressed by a decrease in the immobility of animals subjected to the FST. Our results demonstrated that $T$. parthenium induced a dosedependent reduction of immobility time in the FST at 10, 20, and $40 \mathrm{mg} / \mathrm{kg}$ : this antidepressant effect was similar to that produced by ALP (Rang et al., 1996; Hascoet and Bourin, 1997; Hascoet and Bourin, 1997).

Monoaminergic, serotoninergic, and noradrenergic systems are known to play major roles in major depression (Perona et al., 2008). However, the GABA system also participates in the antidepressant actions of thiazole-BDZ such as ALP that, in addition to enhancing the release of serotonin (5-HT) in the hippocampus to produce antidepressant actions, may act by means of a GABAergic mechanism that is independent of the BDZ-site receptor (Jonas and Cohon, 1993; Kalueff and Nutt, 2007; Al-Tubuly et al., 2008). Thus, as may be observed in Fig. 3, fluoxetine (FLX) was not able to reduce immobility time in the FST, as might be expected. This fact agrees with previous reports on Selective Serotonin Reuptake Inhibitor (SSRI) antidepressant drugs, such as FLX at an acute dose, which does not exert an antidepressantlike effect on the FST (Cassani et al., 2014, 2015).

Interestingly, the combination of a sub-effective dose of FLX $(10 \mathrm{mg} / \mathrm{kg}$ ) in combination with a non-effective dose of $T$. parthenium $(5 \mathrm{mg} / \mathrm{kg})$ revealed to evident antidepressant activity in the FST.

The synergistic antidepressant-like effect produced by a subeffective dose of $T$. parthenium and FLX comprised an interesting result that may derive from the effect of $T$. parthenium in the FST and an interaction with the serotoninergic system. In accordance with our earlier findings, we depleted 5-HT by means of the tryptophan hydroxylase inhibitor $p$-chlorophenylalanine (PCPA) before treatment with TP. PCPA blocked the antidepressant actions of T. parthenium in the FST. These findings support the involvement of the serotoninergic neurotransmitter system in the antidepressant action of $T$. parthenium. In general, a large number of evidences indicate that the serotonin neurotransmitter system is strongly involved in the regulation of mood and anxiety disorders (Millan, 2003). Several pieces of evidence have been implicated in abnormalities in serotonergic transmission in the pathology of depressive disorders. However, we think that it is necessary to perform experiments aimed at determining the specific mechanism underlying the anxiolytic and antidepressant actions of $T$. parthenium.

Previous studies have shown that many psychostimulant drugs can decrease immobility behavior in the FST. These drugs also cause marked increases in the ambulatory activity of the experimental animals. Therefore, to avoid a false positive antidepressant effect, the 
locomotor activity of animals subjected to the FST was evaluated employing the OFT. Our results showed that T. parthenium significantly reduced immobility time in the FST without increasing ambulatory activity, which confirmed that $T$. parthenium induces a clear, antidepressant-like effect in the FST.

In summary, numerous neurotransmitter systems underlie the states of anxiety and depression. It is accepted that BDZ-type anxiolytics act enhancing the effect of GABA at the $\mathrm{GABA}_{\mathrm{A}}$ receptor. Although these classical BDZ are effective anxiolytics, they lack the antidepressant effects. In this study, we demonstrated that $T$. parthenium induced both anxiolytic and antidepressant actions that are mediated, at least in part, by its interaction with $\mathrm{GABA}_{\mathrm{A}}$ receptors. Additionally, our findings also show the involvement of the serotonergic neurotransmitter system in the antidepressant actions of $T$. parthenium.

\section{Conclusions}

This study showed that a single oral treatment of $T$. parthenium induces anxiolytic- and antidepressant-like effects in several behavioral paradigms in mice. $T$. parthenium did not induce alterations in locomotor activity. These results led to evidence of the participation of the GABAergic and serotonergic systems in the actions of $T$. parthenium. Our results support the use of Tanacetum parthenium in traditional medicine and reveal its utility for the treatment of comorbid disorders of depression and anxiety.

\section{Competing interest}

The authors declare no conflict of interest.

The authors declare that they have no competing interests.

\section{Acknowledgments}

The authors are indebted to Carmen Márquez, Erendira García Rios, Lucero Rios and Rubén Gaviño for their technical assistance. Also we appreciate the work of M.V.Z. Mario Aguilar Amaya for animal handling. And Dr. Bernardo Frontana Uribe from Instituto de Química, UNAM.

\section{References}

Al-Tubuly, R.A., Aburawi, S.M., Alghzewi, E.A., Gorash, Z.M., Errwami, S., 2008. The effect of sympathetic antagonists on the antidepressant action of alprazolam. Libyan J. Med. 3 (2), 78-83.

American Mental Association, 2013. Diagnostic and Statistical Manual of Mental Disorders 5th ed.. (DSMV), Washington, DC.

Beleboni, R.O., Carolino, R.O., Pizzo, A.B., Castellan-Baldan, L., Coutinho-Netto, J., dos Santos, W.F., Coimbra, N.C., 2004. Pharmacological and biochemical aspects of GABAergic neurotransmission: pathological and neuropsychobiological relationships. Cell Mol. Neurobiol. 24, 707-728.

Bourbonnais-Spear, N., Award, R., Merali, Z., Maquin, P., Cal, V., Arnason, J.T., 2007. Ethnopharmacological investigation of plants used to treat susto, a folk illnes. J. Ethnopharmacol. 190, 380-387.

Cassani, J., Dorantes-Barrón, A.M., Mayagoitia, L., Alva Real, G., Estrada-Reyes, R. 2014. Involvement of the serotonergic system in the Kaempferitrin antidepressantlike effect in mice. Molecules 19, 21442-21461.

Cassani, J., Ferreyra-Cruz, O.A., Dorantes-Barrón, A.M., Vigueras Villaseñor, R.M., Arrieta-Baez, D., Estrada-Reyes, R., 2015. Antidepressant-like and toxicological effects of a standardized aqueous extract of Chrysactinia mexicana A. Gray (Asteraceae) in mice. J. Ethnopharmacol. 171, 295-306.

Chávez, M., Chávez, P., 1999. Feverfew. Hosp. Pharm. J. 34, 436-461.

De Boer, S., Koolhaas, J., 2003. Defensive burying in rodents: ethology, neurobiology and psychopharmacology. Eur. J. Pharmacol. 463, 145-161.

Diccionario enciclopédico de la medicina tradicional mexicana, 2009. Biblioteca digital de la medicina tradicional Mexicana. Santa María Tanacetum parthenium (L.) Shultz-Bip Compositae. Consulted: [17/01/2017] 〈http://www. medicinatradicionalmexicana.unam.mx/monografia.php?L=3 \& $\mathrm{t}=$ Tanacetum \%20parthenium \& id=7488 .

Estrada-Reyes, R., Martínez-Vázquez, M., Gallegos-Solís, A., Heinze, G., Moreno, J., 2010. Depressant effects of Clinopodium mexicanum Benth. Govaerts (Lamiaceae) on the central nervous system. J. Ethnopharmacol. 130, 1-8.

Estrada-Reyes, R., Lopez-Rubalcava, C., Ferreyra-Cruz, O.A., Dorantes-Barron, A.M.,
Heinze, G., Moreno Aguilar, J., Martinez-Vazquez, M., 2014. Central nervous system effects and chemical composition of two subspecies of Agastache mexicana; an ethnomedicine of Mexico. J. Ethnopharmacol. 153, 98-110.

Hascoet, M., Bourin, M., 1997. Anti-conflict effect of alpidem as compared with the benzodiazepine alprazolam in rats. Pharmacol. Biochem. Behav. 56, 317-324.

Hausen, B.M., 1981. Allergic contact dermatitis due to feverfew Tanacetum parthenium, Asteraceae. Dermatosen in Beruf und Umwelt. Vol. 29, pp. 18-21.

Jäger, A.K., Gauguin, B., Adsersen, A., Gudiksen, L., 2006. Screening of plants used in Danish folk medicine to treat epilepsy and convulsions. J. Ethnopharmacol. 105, 294-300.

Jäger, A.K., Krydsfeldt, K., Rasmussen, H.B., 2009. Biossay-guided isolation of apigenin with GABA-benzodiazepine activity from Tanacetum parthenium. Phytother. Res. $23,1642-1644$.

Jeffrey, C., 2001. Tanacetum parthenium. Mansfeld's World Database of Agricultural and Horticultural Crops. 〈http://mansfeld.ipk-gatersleben.de/apex/f?P=185:4〉.

Jonas, J.M., Cohon, M.S., 1993. A comparison of the safety and efficacy of alprazolam versus other agents in the treatment of anxiety, panic, and depression: a review of the literature. J. Clin. Psychiatry 54, 25-45.

Kalueff, A.V., Nutt, D.J., 2007. Role of GABA in anxiety and depression. Depression Anxiety 24, 495-517.

Kessler, R.C., Birnbaum, H.G., Shahly, V., 2010. Age differences in the prevalence and comorbidity of DSM-IV major depressive episodes: results from the WHO World Mental Health Survey Initiative. Depression Anxiety 27, 351.

Kelsey, C., Collimore, N.A., 2014. Rector.Treatment of Anxiety Disorders With Comorbid Depression: a Survey of Expert CBT Clinicians. Cogn. Behav. Pract. 21, 485-493.

Lamers, F., Van, O.P., Comijs, H.C., Smit, J.H., Spinhoven, P., Van, B.A.J., 2011. Comorbidity patterns of anxiety and depressive disorders in a large cohort study: the Netherlands Study of Depression and Anxiety (NESDA). J. Clin. Psychiatry 72, 342-348.

Lister, R.G., 1987. The use of a plus-maze to measure anxiety in the mouse. Psychopharmacology 92, 180-185.

Long, C., Sauleau, P., David, B., 2003. Bioactive flavonoids of Tanacetum parthenium revisited. Phytochemistry $64,567-569$.

López-Rubalcava, C., Hen, R., Cruz, S.L., 2000. Anxiolytic-like actions of toluene in the burying behavior and plus-maze tests: differences in sensitivity between $5-\mathrm{HT}_{1 \mathrm{~B}}$ knockout and wild-type mice. Behav. Brain Res. 115, 85-94.

López-Rubalcava, C., Pina-Medina, B., Estrada-Reyes, R., Heinze, G., Martinez-Vázquez, M., 2006. Anxiolytic-like actions of the hexane extract from leaves of Annona cherimolia in two anxiety paradigms: possible involvement of the GABA/ benzodiazepine receptor complex. Life Sci. 78, 730-737.

Majdi, M., Liu, Q., Karimzadeh, G., Malboobi, M.A., Beekwilder, J., Cankar, K., Vos, R.R., Todorović, S., Simonović, A., Bouwmeester, H., 2011. Biosynthesis and localization of parthenolide in glandular trichomes of feverfew (Tanacetum parthenium L. Schulz Bip.). Phytochemistry 72, 1739-1750.

Martínez-Vázquez, M., Estrada-Reyes, R., Araujo Escalona, E.A.G., Ledesma Velázquez, I, Martínez-Mota, L.A., Moreno, J., Heinze, G., 2012. Antidepressant-like effects of an alkaloid extract of the aerial parts of Annona cherimolia in mice. J. Ethnopharmacol. 139, 164-170.

Mendenhall, E., Fernandez, A., Adler, N., Jacobs, E.A., 2012. Susto, coraje, and diabetes: depression and beliefs about diabetes. Cult. Med. Psychiatry 36, 480-492.

Millan, M.J., 2003. The neurobiology and control anxious states. Prog. Neurobiol. 70 $83-244$.

Möhler, H., 2006. GABAA Receptors in Central Nervous System Disease: anxiety, Epilepsy, and Insomnia. J. Recept. Signal Transduct. 26, 731-740.

Morimoto, K., Fahnestock, M., Racine, R.J., 2004. Kindling and status epilepticus models of epilepsy: rewiring the brain. Prog. Neurobiol. 23, 1-60.

Olsen, R.W., DeLorey, T.M., 1999. GABA receptor physiology and pharmacology. In: Siegel, G.J., Agranoff, B.W., Albers, R.W. (Eds.), Basic Neurochemistry: Molecular, Cellular and Medical Aspects6th ed.. Lippincott-Raven, Philadelphia, PA, USA.

Pareek, A., Suthar, M., Rathore, G.S., Bansal, V., 2011. Feverfew (Tanacetum parthenium L.): a Systematic Review. Pharmacogn. Rev. 5 (9), 103-110.

Perona, M.T.G., Waters, S., Hall, F.S., Sora, I., Lesch, K.P., Murphy, D.L., Caron, M., Uhl, G.R., 2008. Animal models of depression in dopamine, serotonin and norepinephrine transporter knockout mice: prominent effects of dopamine transporter deletions. Behav. Pharmacol. 19, 566-574.

Petty, F., Trivedi, M.H., Fulton, M., Rush, A.J., 1995. Benzodiazepines as antidepressants: does GABA play a role in depression? Biol. Psychiatry 38, 578-591.

Pinel, J.P., Treit, D., 1978. Burying as a defensive response in rats. J. Comp. Physiol. Psychol. 92, 708-712.

Porsolt, R.D., Le Pichon, M., Jalfre, M., 1977a. Depression: a new animal model sensitive to antidepressant treatment. Nature 266, 730-732.

Porsolt, R.D., Bertin, A., Jalfre, M., 1977b. Behavioral despair in mice: a primary screening test for antidepressant. Arch. Int. Pharmacodyn. Ther. 229, 327-336.

Rang, H.P., Dale, M.M., Ritter, J.M., 1996. Pharmacology. CNS Stimulants and Psychomimetic Drugs Third ed.. Laurence Hunter, New York, London, 634.

Rocha, F.F., Lapa, A.J., Lima, T.T.M., 2002. Evaluation of the anxiolytic-like effects of Cecropia glazioui Sneth in mice. Pharmacol. Biochem. Behav. 71, 183-190.

Sherif, F.M., Ahmed, S.S., 1995. Basic aspects of GABA-transaminase in neuropsychiatric disorders. Clin. Biochem. 28, 145-154.

Treit, D., 1985. The inhibitory effect of diazepam on defensive burying: anxiolytic vs analgesic effects. Pharmacol. Biochem. Behav. 22, 47-52.

Treiman, D.M., 2001. GABAergic mechanisms in epilepsy. Epilepsia 42 (s3), 8-12.

Villaseñor, R.J.L., Espinosa, F.J.G., 1998. Catálogo de malezas de México. Universidad Nacional Autónoma de México. Consejo Nacional Consultivo Fitosanitario. Fondo de Cultura Económica, México, D.F.

Weller, S.C., Baer, R.D., Garcia de Alba, G.J., Salcedo, R.A.L., 2008. Susto and nervios: 
expressions for stress and depression. Cult. Med. Psychiatry 32 (3), 406-420. Williams, C.A., Harborne, B., Eagles, J., 1999a. Variations in lipophilic and polar flavonoids in the genus Tanacetum. Phytochemistry 52, 1301-1306.
Williams, C.A., Harborne, B., Geiger, H., Hoult, J.R.S., 1999b. The flavonoids of Tanacetum parthenium and T. vulgare and their anti-inflammatory properties. Phytochemistry 51, 417-423. 